\title{
Microautoradiographic study of thymidine uptake in brackish waters around Sapelo Island, Georgia, $\mathrm{USA}^{*}$
}

\author{
Carlos Pedrós-Alió ${ }^{1}$, Steven Y. Newell ${ }^{2}$ \\ ${ }^{1}$ Department of Genetics and Microbiology, Autonomous University of Barcelona, 08193 Bellaterra (Barcelona), Spain \\ ${ }^{2}$ University of Georgia Marine Institute, Sapelo Island, Georgia 31327, USA
}

\begin{abstract}
Total cell numbers, thymidine uptake rates, and percent of bacteria labeled with thymidine were determined in a variety of brackish water environments around Sapelo Island. Cell numbers were high compared to other aquatic habitats and varied between $4 \times 10^{6}$ and $3.2 \times 10^{7}$ cells $\mathrm{ml}^{-1}$ (average $1.07 \times 10^{7}$ cells $\mathrm{ml}^{-1}$ ). Thymidine uptake rates were also among the highest published values, up to $425 \mathrm{fmol}$ thymidine $\mathrm{ml}^{-1} \mathrm{~h}^{-1}$ (average $213 \mathrm{fmol}$ thymidine $\mathrm{ml}^{-1} \mathrm{~h}^{-1}$ ). Despite high abundance and activity, the percentage of cells labeled with thymidine (as determined by microautoradiography) was usually low, ranging from 1 to $69 \%$ (average $16 \%$ ). Brackish-water cultures studied in the laboratory showed, at most, $57 \%$ of the bacteria labeled even during exponential growth. Therefore, it was concluded that many actively growing cells did not take up thymidine in these waters. Implications for productivity estimates from thymidine uptake rates are discussed.
\end{abstract}

\section{INTRODUCTION}

The use of several techniques to estimate planktonic bacterial heterotrophic production during the past $10 \mathrm{yr}$ has generated a widely held notion that bacteria are an important component in the flux of energy in planktonic ecosystems (Karl 1979, Fuhrman \& Azam 1980, Ducklow 1982, Kirchman et al. 1982a, Newell \& Fallon 1982, Pedrós-Alió \& Brock 1982, Bell et al. 1983, Riemann et al. 1984). There is a generally felt need of a universal, simple and straightforward method to measure bacterial heterotrophic production, but no such technique seems available yet (van Es \& Meyer-Reil 1982, Staley \& Konopka 1985, Karl 1986, Moriarty 1986). Cole et al. (1988) reviewed the literature and found that, although a variety of techniques had been used, bacterial heterotrophic production was ca $30 \%$ of net primary production in many different aquatic habitats. Despite this general agreement among methods, and due in part to its initial simplicity, the thymidine uptake technique (Fuhrman \& Azam 1980) has become the most widely used to the virtual exclu-

\footnotetext{
- Contribution No. 624 from the University of Georgia Marine Institute
}

sion of other techniques. The thymidine uptake method, however, involves several assumptions which are still being discussed (Fuhrman \& Azam 1982, Findlay et al. 1984, Bell 1986, Moriarty 1986, Hollibaugh 1988)

One of the assumptions involved is that all actively growing bacterial cells do take up thymidine (Fuhrman $\&$ Azam 1982). The only practical way to approach this question is through autoradiography. In fact, the first estimates of growth rates from thymidine uptake were obtained by autoradiography (Brock 1967). More recent studies have addressed the question of how many of the active bacteria take up thymidine in Pacific Ocean coastal waters (Fuhrman \& Azam 1982), seawater and sediment in Halifax Harbor in Canada (Novitsky 1983a, b), a Danish fjord (Riemann et al. 1984), Chesapeake Bay waters (Tabor \& Neihof 1984), a reservoir in Bohemia (Simec 1986), and Atlantic waters off Nova Scotia (Douglas et al. 1987). A wide range of numbers of cells taking up thymidine was found in these studies. However, the number of active cells was either not determined, or was assessed by incorporation of other organic substrates such as amino acids, glucose, or acetate. From such measurements, it can be concluded that a variable proportion of the cells 
taking up amino acids also takes up thymidine. However, in all cases, there was a portion of the active cells which did not take up thymidine. The most striking case was that of the waters off Nova Scotia, where Douglas et al. (1987) found very low percentages of thymidine-active cells (around $13 \%$ of total numbers) while glutamate-active cells were around $61 \%$.

This method of comparison, however, does not yet ensure that all active cells are being detected by using any single compound or combination of compouds. Potentially, there could be many active cells not using any of the compounds tested; for example, bacteria degrading polymeric substances or specialized in fatty acids. We tried to determine the percentage of active cells taking up thymidine under circumstances where we could be reasonably certain that most ( $>99 \%$ ) of the cells were actively growing. The only situation where this is possible with natural populations of bacteria is when using filtration-dilution cultures (Ammerman et al. 1984). Although possibly only a portion of the original community grows in these experiments, those cells growing have to be all actively dividing and producing offspring in order to present exponential growth.

Thus, we analysed thymidine uptake and percent of bacteria labeled through autoradiography both in a variety of brackish water environments around Sapelo Island, and in filtration-dilution cultures with natural communities (here named as brackish-water cultures), to determine the proportion of active bacteria taking up thymidine.

\section{MATERIALS AND METHODS}

Sampling stations were located in different environments around Sapelo Island, Georgia, USA (Fig. 1). General information on the marsh and waters has been summarized by Pomeroy \& Wiegert (1981). Stations were chosen to provide a wide variety of salinities and trophic characteristics. Stn 1 corresponded to a creek as it entered into the marsh area next to a flume used in previous studies (Chalmers et al. 1985, Krambeck \& Newell unpubl.). Stn 2 was located in Post Office creek, a tertiary creek. Stn 3 was in South End creek, next to the Marine Institute. At low tide these 3 creeks contained water masses which during high tide periods flooded the marsh area. At high tide, however, Stns 1 and 2 held water masses which spent low tide periods in the Duplin tidal river, while Stn 3 held a water mass coming from Doboy Sound. Details of water circulation in this area can be found in Ragotzkie \& Bryson (1955) and Imberger et al. (1983). Finally, Stn 4 was located in Doboy Sound, an open estuary, near the ocean.

Subsurface water was collected and taken to the laboratory for immediate processing. Transport took

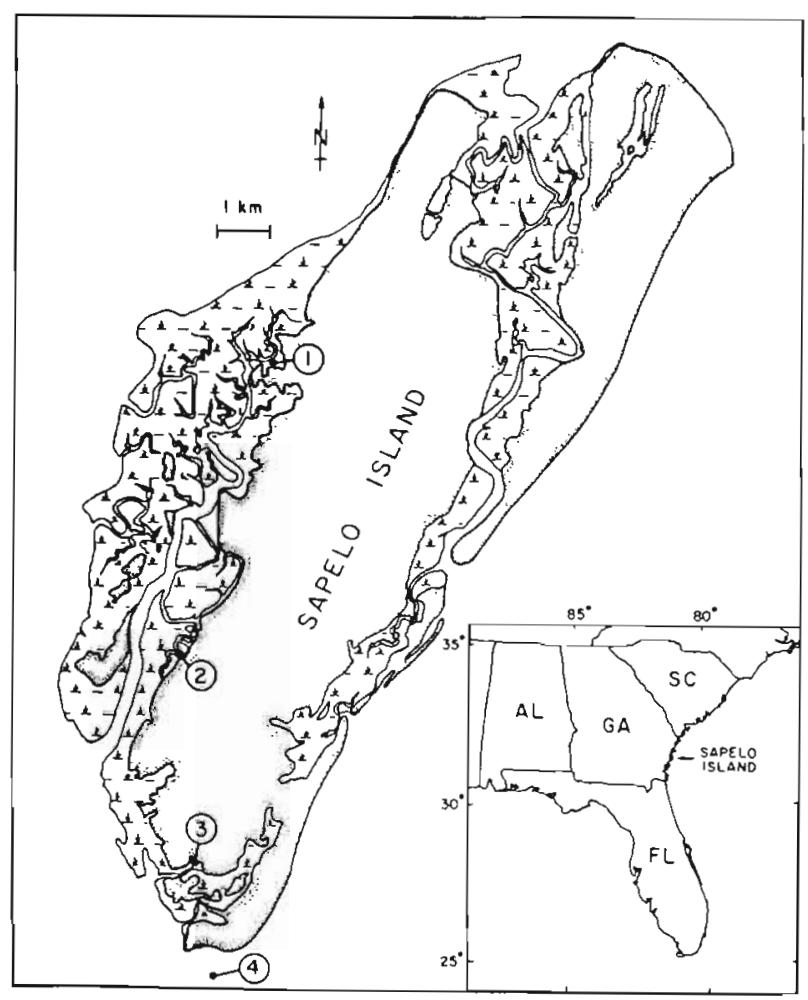

Fig. 1. Locations of stations sampled around Sapelo Island, Georgia, USA. The marsh area where Stns 1 and 2 are located is drained and flooded by the Duplin river. Inset: location of the island on the U.S. east coast

from $5 \mathrm{~min}$, when $\mathrm{Stn} 3$ was sampled, to $30 \mathrm{~min}$, when Stns 1 and 4 were sampled. Temperature was measured in situ with a mercury thermometer. Salinity was determined in the laboratory with a $\mathrm{T}-\mathrm{S}$ Digital salinometer (Tsurumi Seiki).

Cell counts (AODC). Two $10 \mathrm{ml}$ subsamples were placed in scintillation vials with $0.5 \mathrm{ml}$ of sodium borate buffered formalin $(2 \%$ final concentration of formaldehyde). The acridine orange direct count method of Hobbie et al. (1977) was used. Nuclepore filters $(0.2 \mu \mathrm{m}$ pore diameter) were stained in an irgalan black (acid black number 107$)$ solution $(0.2 \% \mathrm{w} / \mathrm{v}$ in $2 \% \mathrm{v} / \mathrm{v}$ acetic acid) for $5 \mathrm{~min}$ and rinsed with filter-sterilized artificial seawater (RILA Products; at $20 \% \mathrm{w} / \mathrm{v}$, with $2 \% \mathrm{v} / \mathrm{v}$ formalin added, herein abbreviated as SASW). Filters were rinsed with filter-sterilized distilled water and used immediately. A $0.45 \mu \mathrm{m}$ pore diameter Gelman filter was used as a subfilter to promote uniform distribution of cells on the Nuclepore filter. Then $1.5 \mathrm{ml}$ of an acridine orange solution $(0.01 \% \mathrm{w} / \mathrm{v}$ in SASW) was added to the filtering set-up and $1 \mathrm{ml}$ of sample added and stained for $1 \mathrm{~min}$. If samples were too concentrated, they were first diluted and then $1 \mathrm{ml}$ placed in the filtering set. Amounts of sample different from $1 \mathrm{ml}$ resulted in low cell fluorescence. Vacuum was applied (about $5 \mathrm{~cm} \mathrm{Hg}$ ) and the sample filtered. The filters were 
not rinsed as this caused fading of the fluorescence. The wet filters were then mounted on microscope slides with immersion oil and observed at $1000 \times$ with a Zeiss epifluorescence microscope (75 W xenon lamp, 487709 exciter/barrier filter set). A minimum of 7 fields per sample were counted (Kirchman et al. 1982b). Green dots with apparent size smaller than $0.01 \mu^{3}$ were not counted as cells (Newell et al. 1986).

Thymidine uptake. Thymidine (TdR) uptake experiments were performed immediately upon arrival to the laboratory. On a few occasions TdR uptake results from samples incubated in Whirl-Pak bags and scintillation vials were compared. Both vials and bags had been previously acid-washed $(1 / 10 \mathrm{v} / \mathrm{v} \mathrm{HCl})$ and thoroughly rinsed with deionized, bacteria-free water. In some cases uptake was higher in bags, in other cases it was higher in scintillation vials. In several further cases no significant differences were observed. Thus, no toxicity of glass was apparent, and both types of containers were used according to convenience.

Two $10 \mathrm{ml}$ experimental samples and one formalinkilled control were incubated at in situ temperature $\left( \pm 1 \mathrm{C}^{\circ}\right)$ for each determination. Essentially, the method of Fuhrman \& Azam (1980) was followed. Each sample received $15 \mu \mathrm{l}$ of a $72 \mathrm{Ci} \mathrm{mmol}^{-1}$ [methyl- ${ }^{3} \mathrm{H}$ ]thymidine solution (ICN Radiochemicals) to give a final concentration of $20 \mathrm{nM}$. According to previous experiments (Riemann et al. 1987) $20 \mathrm{nM}$ Tdr was necessary to saturate the system in these very productive waters. Incubations were carried out in the dark for $30 \mathrm{~min}$ unless otherwise specified. To stop incubations, each vial received $0.5 \mathrm{ml}$ of buffered formalin and was placed in ice in the dark. Samples were filtered on 0.45 um pore diameter Gelman GN 6 membrane filters and rinsed 5 times with ca $3 \mathrm{ml}$ of ice-cold $5 \%$ TCA (Riemann 1984). Filters were then placed in scintillation vials and dissolved with $1 \mathrm{ml}$ of ethyl acetate. It was not necessary to let the filters dry before adding the ethyl acetate, but 60 to $120 \mathrm{~min}$ had to elapse for complete dissolution before $10 \mathrm{ml}$ of Aquasol-2 (New England Nuclear) could be added. Radioactivity was determined in a Beckman liquid scintillation counter and quenching was corrected by a Compton-edge $\left(\mathrm{H}^{*}\right)$ method (Long 1977).

Autoradiography (AU). The method of Meyer-Reil (1978) as adapted by Tabor \& Neihof (1982) was followed with some modifications. Several suggestions from Brock \& Brock (1968) and Paerl \& Stull (1979) were applied in modifying the method. Incubations for AU were performed in the same way as, and simultaneously with, TdR uptake experiments with the exceptions explained below. Incubation times were $4 \mathrm{~h}$ instead of $30 \mathrm{~min}$, since experiments to determine optimal incubation times showed that numbers of labeled cells after 3 to $6 \mathrm{~h}$ of incubation were maximal and not significantly different among them (Fig. 2A). A 0.3 to $0.6 \mathrm{ml}$ aliquot of fixed sample was mixed with $2 \mathrm{ml}$ of filter-sterilized artificial seawater and filtered through a $0.2 \mu \mathrm{m}$ Nuclepore filter (shiny side up, a Gelman $0.45 \mu \mathrm{m}$ filter was used as a subfilter). The filter was rinsed twice with SASW to remove excess radioactivity and the filters were removed from the filtration set without disconnecting the vacuum. Filters were cut into halves and each half was attached to a clean microscope slide with a drop of glycerol. Slides were protected from dust until processed. In the darkroom, and in absolute darkness, slides were dipped in melted NTB-2 nuclear track emulsion (Kodak, diluted $1 / 1$ with filter-sterilized deionized water). Excess emulsion was allowed to drain off for $20 \mathrm{~s}$. Then, the half filters were carefully deposited (the face with bacteria down) on the still-wet emulsion with the momentary aid of a Wratten no. 2 safety light, operated with a foot switch. This step was critical, since gentle, precise placement of filters was necessary to prevent heterogeneous transfer of cells from filter to emulsion and uneven drying. The slides were then allowed to solidify and dry vertically in a test tube rack. During this time, the test tube racks were kept within black polyethylene boxes to prevent dust or light from reaching the emulsion. After 1 to $2 \mathrm{~h}$, slides were placed in microscope slide boxes. These boxes were placed in black containers with desiccant, and the containers were sealed with black tape. The whole package was then wrapped
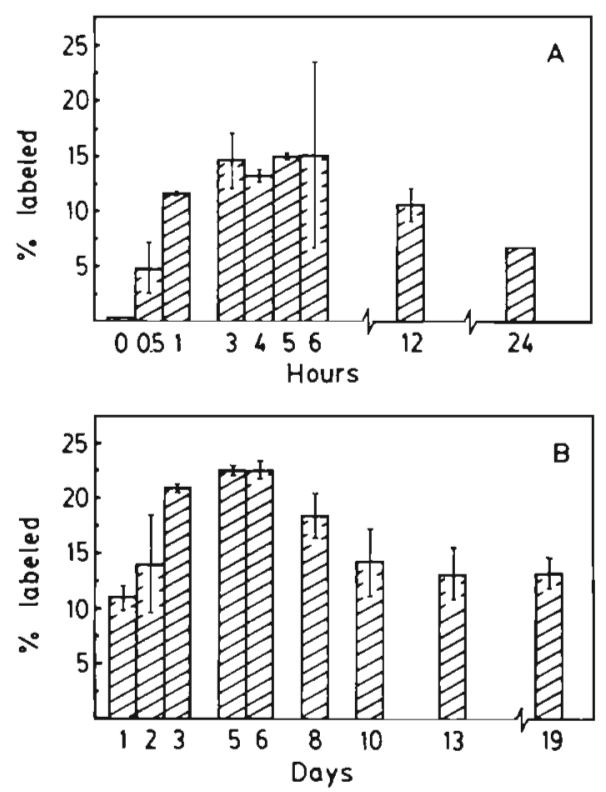

Fig. 2. (A) Percent of bacteria labeled (PBL) after different incubation times (h). Range of 2 replicates is shown. Samples taken at Stn 3 on August 18, 1987. Slides were developed after 5 d of exposure. (B) PBL after different exposure times (d). Samples taken at Stn 3 on August 19, 1987. Samples were incubated for $4 \mathrm{~h}$ 
twice in black plastic bags, taped and labeled. Preliminary experiments to determine optimal exposure time showed that between 3 and $6 \mathrm{~d}$, the numbers of labeled cells were maximal and not significantly different among them (Fig. 2B). Thus, exposure periods of 3 to $4 \mathrm{~d}$ were routinely used. Exposure was conducted at room temperature.

After exposure, the slides were developed for $4 \mathrm{~min}$ in Kodak D-19 developer (diluted 1/1 with distilled water), rinsed $30 \mathrm{~s}$ with distilled water, and fixed in Kodak full strength fixer for $4 \mathrm{~min}$. Then the slides were washed for $10 \mathrm{~min}$ in running tap water and rinsed with distilled water. Throughout this developing process it was convenient to keep the slides in glass trays with a holder. Chemicals were kept in glass staining dishes of the type used for microscopy, and the trays with up to 20 slides could be easily transferred from one liquid to the next.

For our samples, the destaining steps with citrate buffer (Tabor \& Neihof 1982) gave orange-fluorescing cells which were hard to distinguish from background and debris. The same problem was encountered by Newell (1984) for Sapelo waters and we followed suggestions therein. The air-dried slides were placed horizontally on a flat surface and the filter area covered with drops of an acridine orange solution $(0.01 \% \mathrm{w} / \mathrm{v}$ in SASW). When all the liquid had evaporated ( 3 to $4 \mathrm{~h}$ ) the slides were given 2 rinses of distilled water and transferred to glass slide trays. The trays were submerged in distilled water for $10 \mathrm{~min}$ and in a $1 \%$ glycerol solution ( $\mathrm{v} / \mathrm{v}$ in distilled water) for $1 \mathrm{~min}$ before letting them dry again in air or in a desiccator under vacuum. Once dry, the filters were carefully peeled off with forceps. Periodical examination of the filters never showed any cells remaining on them. The slides could be kept for several days in microscope slide boxes until examined. For counting, immersion oil was placed directly above the emulsion (without coverslip) and the preparations observed at $1000 \times$ with a Zeiss epifluorescence microscope. Transmitted light was adjusted so that it would not mask the fluorescence and used simultaneously to detect exposed silver grains in the emulsion.

In experiments with natural samples no difference in total cell numbers was detected between AU preparations and corresponding AODC preparations. In growth experiments with diluted brackish-water cultures, however, cell numbers increased during the $4 \mathrm{~h}$ AU incubations, especially when samples from the exponential phase of growth were analysed. In these cases, percent of bacteria labeled had to be calculated with respect to total cell number in the AU preparations. Since 2 samples were available for each data point and 2 half filters were processed for each sample, we had 4 replicates for each data point. Controls without radioactivity and formalin-killed before adding the radioactivity were also run. These never showed labeled cells. Occasionally, 2 or 3 silver grains would appear on a cell, but even if these were counted as labeled cells, the total number of labeled cells in controls was negligible when compared to experimental samples.

Under the microscope, labeled cells showed a thick crown of exposed silver grains after 3 to $4 \mathrm{~h}$ incubations, which clearly distinguished them from unlabeled cells despite some background grains (Fig. 3). However, cells with more than 2 silver grains (on the few occasions when they appeared) were also counted as labeled in order to obtain the maximum possible numbers of labeled cells (see 'Discussion').

Brackish-water cultures. The method of Ammerman et al. (1984) was followed. Water samples from the creek at Stn 1 were collected in sterile glass bottles. Part of the water was filtered through $0.8 \mu \mathrm{m}$ Nuclepore filters (45 mm diameter) to provide a bacterial inoculum without bacterial predators. Part of the water was filtered through $0.2 \mu \mathrm{m}$ Nuclepore filters $(45 \mathrm{~mm}$ diameter) to provide a natural sterile medium. The inoculum was diluted ca 10 times with the medium and incubated at in situ temperature in the dark. Samples were collected periodically and AODC, TdR uptake and $\mathrm{AU}$ determined. In one case frequency of dividing cells (FDC; Hagström et al. 1979) was also measured according to Newell \& Christian (1981).

\section{RESULTS}

Results from brackish-water cultures are shown in Figs, 4 and 5 for 2 different dates: August 25 and September 16, 1987. Both experiments were run with water from Stn 1. Lag periods in cell growth between 5 and $8 \mathrm{~h}$ were observed in both cases. Summary data for these 2 experiments are presented in Table 1 . In the August experiment, the culture grew back to the natural cell concentration (around $10^{7}$ cells $\mathrm{ml}^{-1}$ ), the lag phase was shorter, and growth rate faster than in the September experiment. The decrease in TdR uptake upon reaching the stationary phase of growth was also faster in the August experiment. Activities per cell, however, showed similar patterns and were in fact lower in the August experiment ( 8 vs $12 \mathrm{fgC} \mathrm{cell}^{-1} \mathrm{~h}^{-1}$ ). The percentages of bacteria labeled (PBL) in AU preparations were always lower than $60 \%$. In both cases PBL was lower during Iag and stationary phases and increased during log phase (Figs. $4 \mathrm{~B}$ and $5 \mathrm{~B}$ ). There seemed to be a good correspondence between PBL and FDC in the September experiment (Fig. 5B). Maximal PBL were $57 \%$ in the August and $37 \%$ in the September experiment (Fig. 5B; Table 1). Volume of cells was considerable higher during the log phase than 

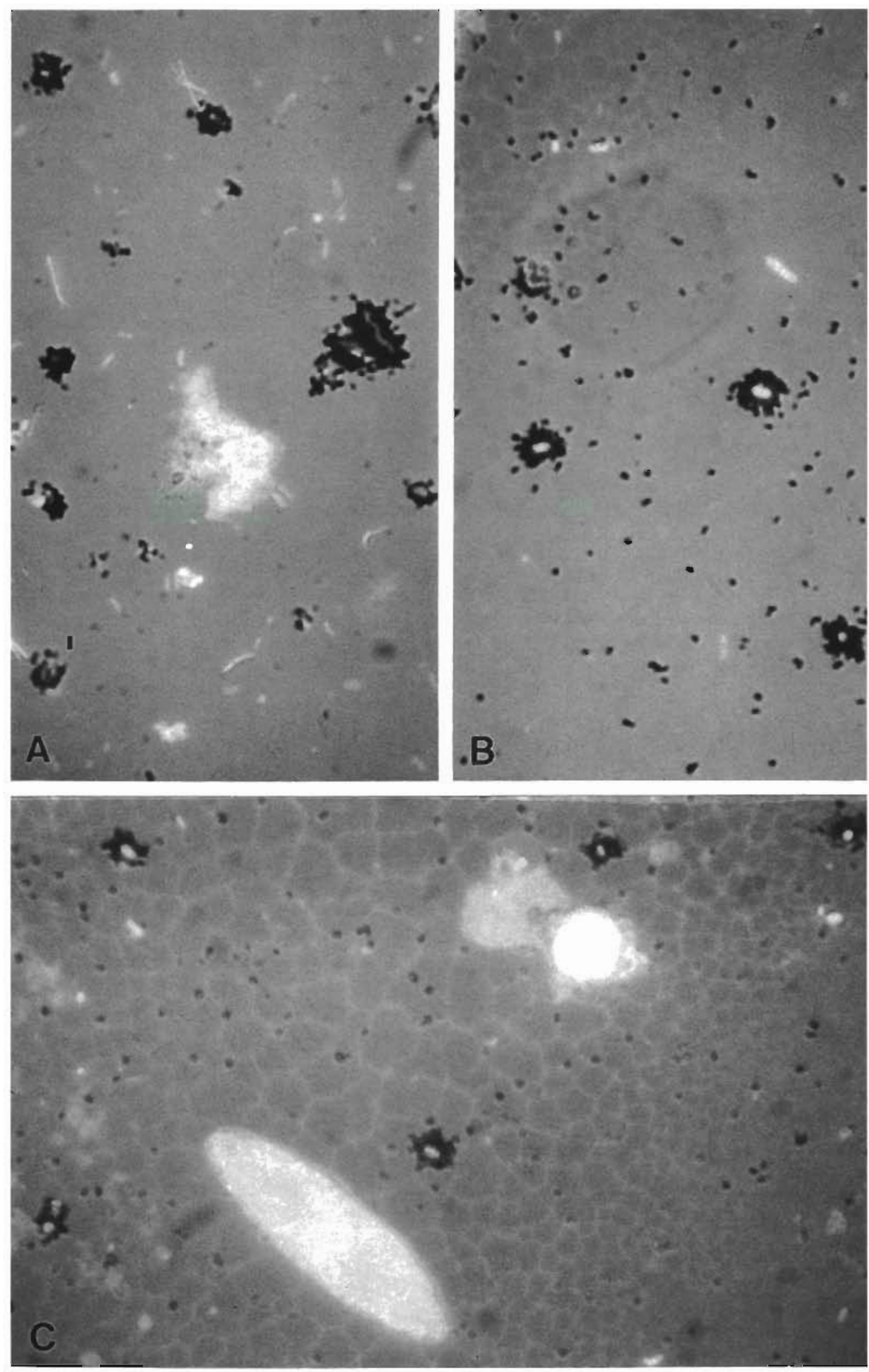

Fig.3. Microautoradiograms of cells incubated with ${ }^{3} \mathrm{H}$-thymidine for $4 \mathrm{~h}$. Exposure time was $3 \mathrm{~d}$. Notice abundance of unlabeled cells. (A) Natural sample. (B) Diluted brackish-water culture. (C) Natural sample with unlabeled protists 


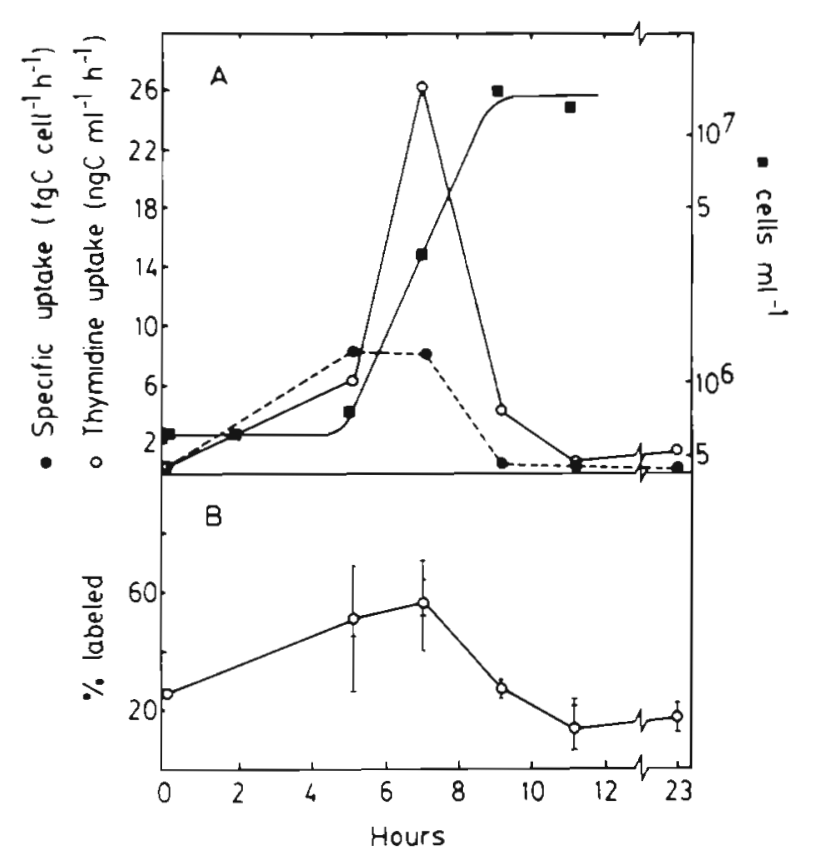

Fig.4. Brackish-water culture experiment performed on August 25, 1987 with sample from Stn 1. (A) Changes with time of total cell number (-), thymidine uptake in $\mathrm{ng} \mathrm{C} \mathrm{ml} \mathrm{Cl}^{-1}$ $\mathrm{h}^{-1}(\mathrm{O})$ and specific thymidine uptake in $\mathrm{fg} \mathrm{C}_{\text {cell }}{ }^{-1} \mathrm{~h}^{-} \mathrm{u} 21(\bullet)$ (B) PBL through time (0). Vertical bars indicate range of values for quadruplicate samples. Horizontal bars indicate actual values of each quadruplicate

during lag and stationary phases of growth (data not shown).

Range of PBL in natural environments was studied by sampling many different water masses (Table 2). In this way variability due to tidal cycles, differences in salinities and temperatures, different degrees of organic matter content and day to day changes could be determined. High vs low tides were compared at Stn 3. Day to day changes, as well as influence of rainfall, were studied at Stns 2, 3 and 4. Finally, values from Stns 2 and 4 corresponded to water masses with different trophic status.

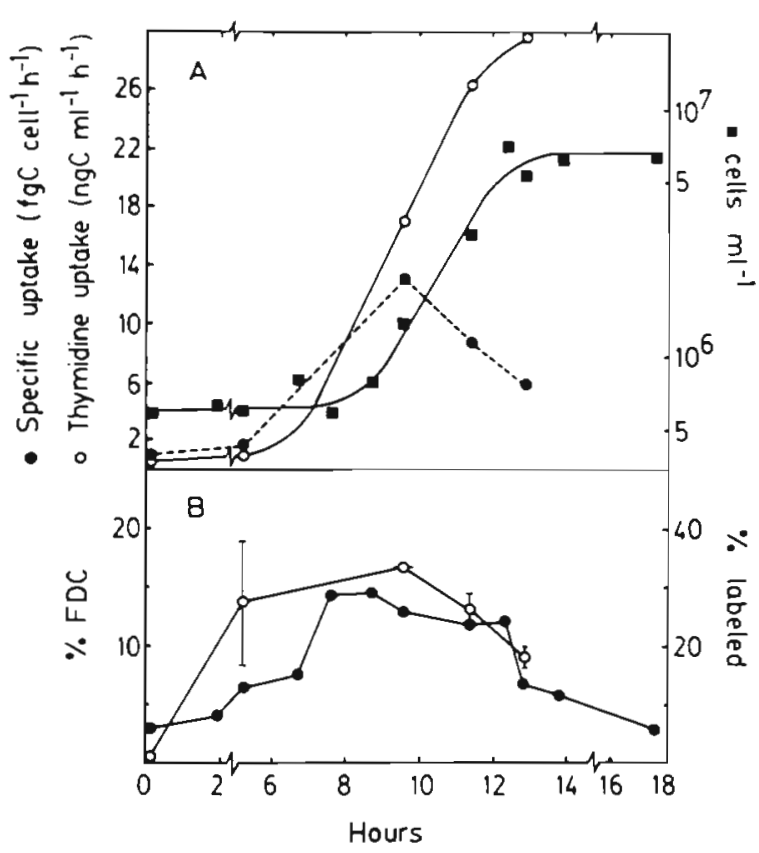

Fig. 5. Brackish-water culture experiment performed on September 16, 1987 with sample from Stn 1. (A) Changes with time of total cell number $(\boldsymbol{\oplus})$, thymidine uptake in $\mathrm{ng} \mathrm{C} \mathrm{ml}^{-1}$ $\mathrm{h}^{-1}(\mathrm{O})$ and specific thymidine uptake in $\mathrm{fg} \mathrm{C}_{\mathrm{C}} \mathrm{cell}^{-1} \mathrm{~h}^{-1}(\bullet)$. (B) PBL through time $(0)$ and frequency of dividing cells $(\bullet)$. Vertical bars indicate range of values of quadruplicate samples

These stations were very different in their microbiological characteristics. Average values for $\mathrm{TdR}$ uptake, AODC, PBL, temperature and salinity were significantly different by Kruskal-Wallis tests. Specific activity per total cell number and per thymidine active cells was also very different among the stations (see average values for each station in Table 2).

AODC, TdR uptake and PBL were followed for 9 consecutive days, $1 \mathrm{~h}$ before low slack tide, at $\operatorname{Stn} 3$ (Fig. 6). Bacterial productivity and specific activity were higher after heavy rainfalls and slowly returned to lower values after 2 to $3 \mathrm{~d}$ periods of sunny

Table 1. Background data for the brackish-water culture experiments shown in Figs. 4 and 5

\begin{tabular}{|c|c|c|}
\hline Parameter & August 25 & September 16 \\
\hline Time & $13: 20$ & $10: 44$ \\
\hline Tidal cycle & Low slack & $E b b$ \\
\hline Temperature $\left({ }^{\circ} \mathrm{C}\right)$ & 33.5 & 29.5 \\
\hline Salinity $(\%)$ & 22.0 & 18.7 \\
\hline AODC (cells $\mathrm{ml}^{-1}$ ) & $\approx 10^{7}$ & $3.56 \times 10^{7}$ \\
\hline Final AODC (cells ml-1) & $1.30 \times 10^{7}$ & $6.26 \times 10^{6}$ \\
\hline Maximal \% of labeled cells & 57 & 37 \\
\hline Growth rate $\left(h^{-1}\right)$ & 0.738 & 0.433 \\
\hline Generation time (h:min) & $0: 56$ & $1: 34$ \\
\hline Conversion factor (cells mmole ${ }^{-1}$ ) & $5.28 \times 10^{18}$ & $2.62 \times 10^{18}$ \\
\hline $\operatorname{FDC}(\%)$ & - & 12.5 \\
\hline
\end{tabular}


Table 2. Chemical parameters, cell numbers and activity measurements at 3 stations: South End creek (Stn 3), Doboy Sound (Stn 4), and Post Office creek (Stn 2). Values for South End creek have been separated into those determined at high and low tide

\begin{tabular}{|c|c|c|c|c|c|c|c|}
\hline Date & $\begin{array}{l}\text { Salinity } \\
(\%)\end{array}$ & $\begin{array}{c}\text { Temperature } \\
\left({ }^{\circ} \mathrm{C}\right)\end{array}$ & $\begin{array}{c}\text { AODC } \\
\left(\text { cells } \mathrm{ml}^{-1}\right)\end{array}$ & $\begin{array}{c}\text { TdR uptake } \\
\text { (fmol ml-1 } \mathrm{h}^{-1} \text { ) }\end{array}$ & $\begin{array}{c}\mathrm{PBL}^{\mathrm{a}} \\
(\% \mathrm{AODC})\end{array}$ & $\begin{array}{c}\text { Sp TdR } \\
\text { (TdR/AODC) }\end{array}$ & $\begin{array}{c}\text { Sp AUc } \\
\text { (TdR/PBL) }\end{array}$ \\
\hline \multicolumn{8}{|c|}{ South End (high) } \\
\hline Jul 28 & 29.3 & 29.0 & $1.14 \times 10^{7}$ & 187 & 3.1 & $1.64 \times 10^{-5}$ & $5.30 \times 10^{-4}$ \\
\hline Aug 11 & 33.3 & 30.0 & $9.49 \times 10^{6}$ & 230 & 5.8 & $2.42 \times 10^{-5}$ & $4.18 \times 10^{-4}$ \\
\hline Mean & 31.3 & 29.5 & $1.04 \times 10^{7}$ & 209 & 4.5 & $2.03 \times 10^{-5}$ & $4.74 \times 10^{-4}$ \\
\hline \multicolumn{8}{|c|}{ South End (low) } \\
\hline Jul 16 & 26.0 & 28.3 & $1.38 \times 10^{7}$ & 140 & 17.3 & $1.01 \times 10^{-5}$ & $5.84 \times 10^{-5}$ \\
\hline Jul 28 & 30.7 & 32.0 & $1.25 \times 10^{7}$ & 250 & 18.2 & $2.00 \times 10^{-5}$ & $1.10 \times 10^{-4}$ \\
\hline Aug 5 & 30.9 & 30.5 & $9.69 \times 10^{6}$ & 172 & $n d^{d}$ & $1.78 \times 10^{-5}$ & nd \\
\hline Aug 11 & 31.6 & 35.0 & $1.59 \times 10^{7}$ & 331 & 10.8 & $2.08 \times 10^{-5}$ & $1.93 \times 10^{-4}$ \\
\hline Aug 18 & 15.7 & 28.5 & $1.22 \times 10^{7}$ & 425 & 13.1 & $3.48 \times 10^{-5}$ & $2.66 \times 10^{-4}$ \\
\hline Aug 19 & 19.7 & 30.0 & $9.31 \times 10^{6}$ & 239 & 22.5 & $2.57 \times 10^{-5}$ & $1.14 \times 10^{-4}$ \\
\hline Aug 20 & 23.9 & 30.0 & $9.85 \times 10^{6}$ & 136 & 39.5 & $1.38 \times 10^{-5}$ & $3.50 \times 10^{-5}$ \\
\hline Aug 21 & 13.8 & 29.0 & $6.76 \times 10^{6}$ & 299 & 39.9 & $4.42 \times 10^{-5}$ & $1.11 \times 10^{-4}$ \\
\hline Aug 22 & 21.0 & 30.0 & $5.80 \times 10^{6}$ & 209 & 68.7 & $3.60 \times 10^{-5}$ & $5.25 \times 10^{-5}$ \\
\hline Aug 23 & 22.5 & 31.0 & $8.68 \times 10^{6}$ & 298 & 54.6 & $3.43 \times 10^{-5}$ & $6.29 \times 10^{-5}$ \\
\hline Aug 24 & 26.3 & 31.0 & $8.61 \times 10^{6}$ & 248 & 38.4 & $2.88 \times 10^{-5}$ & $7.50 \times 10^{-5}$ \\
\hline Aug 25 & 27.3 & 32.0 & $2.09 \times 10^{7}$ & 423 & 11.0 & $2.02 \times 10^{-5}$ & $1.84 \times 10^{-4}$ \\
\hline Aug 26 & 28.9 & 33.0 & $3.17 \times 10^{7}$ & 194 & 3.7 & $6.12 \times 10^{-5}$ & $1.65 \times 10^{-4}$ \\
\hline Mean & 24.5 & 30.8 & $1.27 \times 10^{7}$ & 259 & 28.1 & $2.41 \times 10^{-5}$ & $1.19 \times 10^{-4}$ \\
\hline \multicolumn{8}{|c|}{ Doboy Sound } \\
\hline Sep 2 & 29.1 & 30.0 & $4.10 \times 10^{6}$ & 70 & nd & $1.71 \times 10^{-5}$ & nd \\
\hline Sep 3 & 29.5 & 29.0 & $4.00 \times 10^{6}$ & 70 & nd & $1.75 \times 10^{-5}$ & nd \\
\hline Sep 4 & 28.6 & 29.0 & $5.10 \times 10^{6}$ & 26 & nd & $5.10 \times 10^{-6}$ & $\mathrm{nd}$ \\
\hline Sep 8 & 23.5 & 29.0 & $6.40 \times 10^{6}$ & 94 & nd & $1.47 \times 10^{-5}$ & nd \\
\hline Sep 9 & 21.2 & 29.0 & $9.30 \times 10^{6}$ & 139 & nd & $1.50 \times 10^{-5}$ & nd \\
\hline Sep 10 & nd & 29.5 & $6.90 \times 10^{6}$ & 66 & nd & $9.57 \times 10^{-6}$ & nd \\
\hline Sep 13 & 24.2 & 28.0 & $5.00 \times 10^{6}$ & 91 & 2.6 & $1.82 \times 10^{-5}$ & $7.00 \times 10^{-4}$ \\
\hline Sep 14 & 24.7 & 28.0 & $5.40 \times 10^{6}$ & 96 & 2.8 & $1.78 \times 10^{-5}$ & $9.39 \times 10^{-4}$ \\
\hline Sep 17 & nd & nd & $5.10 \times 10^{6}$ & 112 & 7.9 & $2.20 \times 10^{-5}$ & $2.78 \times 10^{-4}$ \\
\hline Mean & 25.8 & 28.9 & $5.70 \times 10^{6}$ & 86 & 3.8 & $1.53 \times 10^{-5}$ & $6.38 \times 10^{-4}$ \\
\hline \multicolumn{8}{|c|}{ Post Office } \\
\hline Sep 2 & 19.4 & 28.0 & $1.15 \times 10^{7}$ & 404 & nd & $3.51 \times 10^{-5}$ & nd \\
\hline Sep 3 & 18.3 & 26.5 & $1.37 \times 10^{7}$ & 276 & 2.9 & $2.02 \times 10^{-5}$ & $6.95 \times 10^{-4}$ \\
\hline Sep 4 & 20.1 & 26.3 & $1.26 \times 10^{7}$ & 109 & nd & $8.65 \times 10^{-6}$ & nd \\
\hline Sep 8 & 19.5 & 31.0 & $1.24 \times 10^{7}$ & 245 & nd & $1.98 \times 10^{-5}$ & nd \\
\hline Sep 9 & 19.7 & 31.0 & $1.92 \times 10^{7}$ & 305 & nd & $1.59 \times 10^{-5}$ & nd \\
\hline Sep 10 & nd & 32.0 & $1.35 \times 10^{7}$ & 288 & 0.9 & $2.13 \times 10^{-5}$ & $2.37 \times 10^{-3}$ \\
\hline Sep 13 & 18.7 & 27.0 & $1.00 \times 10^{7}$ & 222 & 2.4 & $2.22 \times 10^{-5}$ & $9.25 \times 10^{-4}$ \\
\hline Sep 14 & 18.3 & 28.0 & $1.22 \times 10^{7}$ & 245 & 4.0 & $2.01 \times 10^{-5}$ & $5.02 \times 10^{-4}$ \\
\hline Sep 15 & 18.6 & 29.0 & $1.23 \times 10^{7}$ & 336 & 1.6 & $2.73 \times 10^{-5}$ & $1.71 \times 10^{-3}$ \\
\hline Sep 17 & nd & nd & $1.22 \times 10^{7}$ & 395 & 13.9 & $3.24 \times 10^{-5}$ & $2.33 \times 10^{-4}$ \\
\hline Mean & 19.1 & 28.8 & $1.30 \times 10^{7}$ & 283 & 4.3 & $2.23 \times 10^{-5}$ & $1.07 \times 10^{-3}$ \\
\hline \multicolumn{8}{|c|}{$\begin{array}{l}{ }^{a} \text { Percent of total bacteria labeled in autoradiograms } \\
\text { b Specific TdR uptake in fmol TdR cell }{ }^{-1} \mathrm{~h}^{-1} \text { (TdR uptake divided by AODC) } \\
\text { c Specific TdR uptake in fmol TdR (active cell) })^{-1} \mathrm{~h}^{-1} \text { (TdR uptake divided by TdR active cells) } \\
\text { nd: not determined }\end{array}$} \\
\hline
\end{tabular}

weather. Average PBL values varied substantially, between 3.7 and $68.7 \%$. On August 22, one of the replicates showed a high value (89\%) while the other replicate indicated a more moderate value $(49 \%)$. Other than this, all replicates showed very good agreement (Fig. 6).
When samples from consecutive high and low tides were compared for Stn 3, TdR uptake and PBL were always higher at low tide than at high tide, while cell numbers were similar (Table 2). PBL were between 3 and $6 \%$ at high tide (average $4.5 \%$ ) and between 4 and $69 \%$ at low tide (average $28.1 \%$ ). 


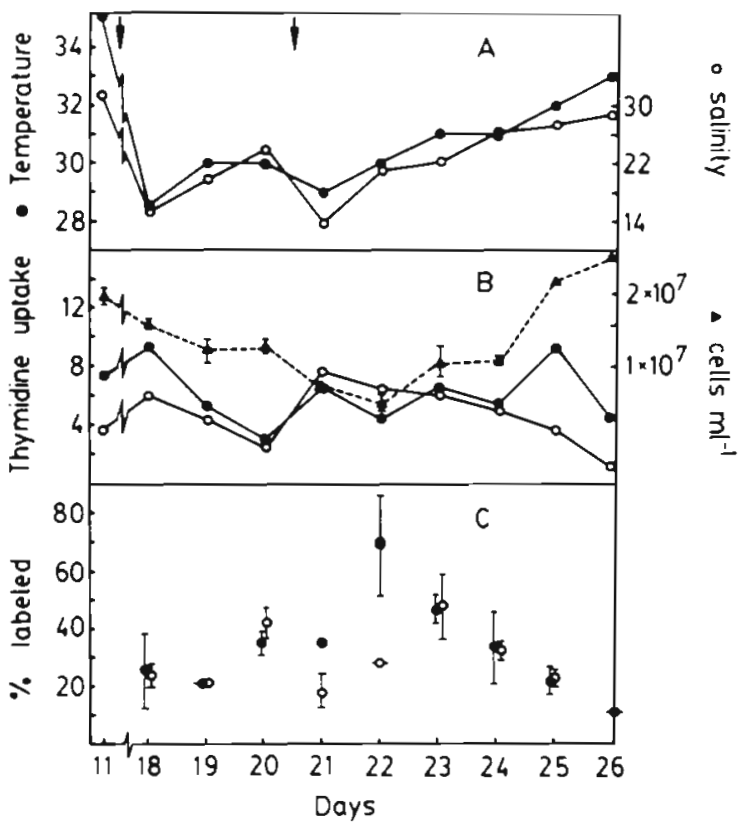

Fig. 6. Variations with time of several parameters at Stn 3. All samples were taken $1 \mathrm{~h}$ before low slack tide on consecutive days. (A) Temperature $\left({ }^{\circ} \mathrm{C}\right)(\bullet)$, and salinity (ppt) (O). Arrows indicate preriods of rainfall: $150 \mathrm{~mm}$ of water fell between August 12 and 17 , and $40 \mathrm{~mm}$ on August 20. (B) Thymidine uptake in $\mu \mathrm{gC}^{-1} \mathrm{~h}^{-1}(\bullet)$, specific thymidine uptake in ng $\mathrm{C}$ cell ${ }^{-1} \mathrm{~h}^{-1} \times 10^{7}(\mathrm{l})$, and total cell abundance in cells $\mathrm{ml}^{-1}(\mathbf{\Delta})$. (C) PBL, open and filled circles correspond to replicate incubations. Vertical bars show range of replicates from each incubation (see 'Materials and methods')

Samples collected simultaneously at low slack tide from Stns 2 and 4 on 10 different occasions were also analysed (Table 2). AODC and TdR uptake were lower in the open estuary (Stn 4) than the marsh creek (Stn 2), as a reflection of the trophic state of both water masses. Cell numbers ranged from $4.0 \times 10^{6}$ to $9.3 \times 10^{6}$ cells $\mathrm{ml}^{-1}$ at Doboy Sound and from $1.0 \times 10^{7}$ to $1.9 \times 10^{7}$ cells $\mathrm{ml}^{-1}$ at the Post Office creek station. TdR uptake varied

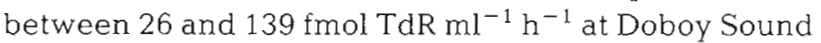
and between 109 and $404 \mathrm{fmol} \mathrm{TdR} \mathrm{ml}^{-1} \mathrm{~h}^{-1}$ at Post Office creek (Table 2). Doubling times for the whole heterotrophic community ranged from 0.7 to $8.3 \mathrm{~d}$.

When Spearman correlation coefficients were calculated among the different variables very few significant correlations were observed. Salinity and temperature were slightly correlated $(x=0.604, p<0.001)$. This was due to the effects of rainfall, which both diluted and cooled the water in the upper stations. Some correlations were spurious, such as that between AODC and specific activity for $\mathrm{TdR}$ uptake $(r=-0.470,0.01>p>$ $0.001)$, since $A O D C$ is used in the calculations of specific activity. PBL was significantly correlated with specific activity $(r=0.581, p<0.001)$ but not with total activity $(r=0.093)$ or cell number $(r=-0.302)$. Since $\mathrm{PBL}$ and specific activity are independently measured, this may be considered a valid correlation. However, if specific activity was calculated per labeled cell a spurious negative correlation was obtained $(r=-0.571,0.01$ $>p>0.001)$. Thus, the only interesting relationship was that between specific activity and number of thymidine-active cells

\section{DISCUSSION}

Productivity estimates from thymidine uptake in waters around Sapelo Island were among the highest reported in the literature. In the present work, productivities up to $9.3 \mu \mathrm{gC} \mathrm{l}^{-1} \mathrm{~h}^{-1}$ were found (with a conservative conversion factor of $1.1 \times 10^{18}$ cells mol ${ }^{-1} \mathrm{TdR}$, and similar values were reported by Newell \& Fallon (1982), Fallon et al. (1986) and Newell et al. (1988). For comparison, spring values in Lake Norvikken (Sweden) reached up to $7.1 \mu \mathrm{gC} \mathrm{l}^{-1} \mathrm{~h}^{-1}$ (Bell et al. 1983), and $3 \mu \mathrm{gC}^{-1} \mathrm{~h}^{-1}$ was the maximal value both in Western US coastal waters (Fuhrman \& Azam 1980) and in the York River (Virginia, USA) estuary (Ducklow 1982). Cell concentrations determined by AODC were also among the highest for aquatic systems (up to $3.2 \times 10^{7}$ cells $\mathrm{ml}^{-1}$ in the present study).

Values of productivity estimated for these waters by FDC (Newell \& Christian 1981, Newell \& Fallon 1982) were up to 10 times higher than those calculated from TdR uptake. The highest value reported by Newell \& Christian (1981), $17.6 \mu \mathrm{gC} \mathrm{l}^{-1} \mathrm{~h}^{-1}$, compares well with productivity estimates of other eutrophic aquatic systems in which productivity was estimated by other techniques. For example, maximal values in eutrophic Lake Mendota (Wisconsin, USA) were around $8 \mu \mathrm{gC} \mathrm{l}^{-1}$ $\mathrm{h}^{-1}$ from FDC and sulfate uptake (Pedrós-Alió \& Brock 1982), $10 \mu \mathrm{gC} \mathrm{l}^{-1} \mathrm{~h}^{-1}$ was the maximal productivity for Lake Mossø (Denmark) (Riemann et al. 1982) by dark $\mathrm{CO}_{2}$ uptake, and the Kiel Fjord (F. R. Germany) (Bölter 1981) from turnover of DOC. This would suggest that TdR estimates are underestimations (or estimates from all other techniques are overestimations) of real productivity.

The percentages of total bacterial cells active in $T d R$ uptake in the present samples were very low: average $16 \%$, never higher than $69 \%$ (except for one outlier replicate of $89 \%$ ). If all cells were able to take up $T d R$, this would argue for a substantial percentage of inactive cells in the community. A review of literature values for percent of cells taking up $T d R$, however, reveals 2 usually ignored facts: first, numbers of TdRactive cells are always lower than numbers of cells taking up amino acids (Hoppe 1977. Fuhrman \& Azam 1982, Novitsky 1983a, Tabor \& Neihof 1984, Douglas et al. 1987), and second, the percentages of cells taking up TdR are usually low: 34 to $54 \%$ in California coastal 
waters (Fuhrman \& Azam 1982), less than 20\% in Halifax Harbor (Novitsky 1983a), 20 to $80 \%$ (average $51 \%$ ) in late summer and 17 to $35 \%$ (average $24 \%$ ) in the fall in Limfjord (Riemann et al. 1984), 6 to $81 \%$ (average $37 \%$ ) in Chesapeake Bay (Tabor \& Neihof 1984), and only from 9.5 to $12.7 \%$ in waters off the coast of Nova Scotia (Douglas et al. 1987). Therefore, most of the published values, corresponding to fairly different environments, are rather low and similar to our own values. This suggests that not all active bacteria are taking up $\mathrm{TdR}$, and that the proportion of these bacteria unable to take up $T d R$ is different in different environments. Perhaps this is why productivity estimates from TdR tend to be lower than those from other techniques.

The most persuasive evidence in favor of the assertion that not all active cells take up TdR is given by the brackish-water culture experiments. Conceivably, a series of populations could be growing and stopping one after the other. This would cause a roughly exponential overall growth with part of the population effectively inactive. However, this possibility is highly unlikely. The populations would have to show the same size distribution, since no changes were observed along the experiments. The populations would have to grow with an extremely precise timing and with incredibly fast growth rates with the precise values to mimic the overall exponential growth. In fact, Newell \& Riemann (unpubl.) found in this type of experiment that the number of INT-respiring cells would increase from a low $20 \%$ during the lag phase to $99 \%$ during the exponential phase, indicating that practically all bacteria were respiring. It could be argued that cells could be respiring without growing, but this would make the succession of populations growing one after the other even a more weird phenomenon. Once can reasonably assume that practically all bacteria are actively growing and dividing during the exponential. phase of growth in such experiments (Ammerman et al. 1984). Despite this, only $57 \%$ of the cells, at most, were detected as actively taking up TdR during the exponential phase of growth in the present work. This is evidence that not all active cells take up TdR in Sapelo waters and, probably, this is also true for many other systems. This statement has to be qualified, however: in autoradiographic studies there is always the possibility that some cells take up the radiolabel, but not enough radioactivity is emitted to expose a silver grain during the exposure period used (Fuhrman \& Azam 1982, Novitsky 1983b, Douglas et al. 1987).

There are 5 reasons why cells in autoradiograms would not be labeled:

(a) The community could potentially be inhibited in the TdR uptake experiments. However, all containers were thoroughly rinsed with distilled water before adding the samples, and the only compound added was $\mathrm{TdR}$ in tracer amounts. Moreover, TdR uptake values in these experiments were always high. Thus, it is unlikely that any sort of inhibition could take place in the experiments.

(b) The cells could be dead or dormant, and thus TdR would not be necessary. This was certainly not the case in the brackish-water cultures as discussed above. Therefore, at least for such cultures, this possibility can be rejected.

(c) Cells could be metabolically active (for example, respiring) but not synthesizing DNA. That is, cells would be under unbalanced growth conditions. Although unbalanced growth is likely in natural populations, it has to be necessarily transient, and could not go on indefinitely for actively growing communities, as shown by exponential growth (cultures) of high productivities and heavy predatory daily losses to ciliates and flagellates without changes in biomass (natural samples; Sherr \& Sherr 1987, Sherr et al. 1989).

(d) Cells are actively growing and replicating their DNA, but they lack the necessary enzymes to transport $T d R$, or they do not use external TdR (they prefer the de novo pathway).

(e) Cells take up TdR and use it for growth, but they grow slowly and take up so little that no silver grains are exposed after the incubation and exposures times used. This possibility seems remote for the brackishwater cultures with doubling times around $1 \mathrm{~h}$, and unlikely for the natural samples with doubling times between 4 and $6 \mathrm{~h}$.

Possibility (d) seems the most likely. This implies that TdR uptake does not measure bacterial heterotrophic production by the whole community. It measures only that part of the community that, at saturating thymidine concentration, uses mostly exogenous thymidine in DNA synthesis. Actually, this is what we could expect from what is known about bacterial physiology. Most organisms, even Escherichia coli, are not capable of taking up all compounds from their environment.

How many molecules of TdR must a cell incorporate in order to emit enough $\beta$ particles during exposure to expose at least 2 silver grains (our lower limit to score a cell as labeled)? The $\left[{ }^{3} \mathrm{H}\right.$-methyl $]$-thymidine we used had a specific activity of $72 \mathrm{Ci} \mathrm{mmole} \mathrm{m}^{-1}$. Since $1 \mathrm{mmol}$ of TdR has $6.023 \times 10^{20}$ molecules of TdR (Avogadro's number times $\left.10^{-3}\right)$, this means that there are $\left[72 \mathrm{Ci} /\left(6.023 \times 10^{20}\right)\right]=1.195 \times 10^{-19} \mathrm{Ci}$ molecule ${ }^{-1}$. Since $1 \mathrm{Ci}=2.22 \times 10^{12} \mathrm{dpm}, 1$ molecule of our TdR had $\left(2.22 \times 10^{12}\right) \times\left(1.195 \times 10^{-19}\right)=2.65 \times 10^{-7} \mathrm{dpm}$ molecule ${ }^{-1}$.

The genofore of an average bacterium has ca $3.2 \times 10^{6}$ base pairs (Ingraham et al. 1983) and, assuming that in a mixed community half of the base pairs are $\mathrm{A}-\mathrm{T}$, the complete genofore will contain $1.6 \times 10^{6}$ thy- 
mines. In order to replicate its DNA once, a cell has to incorporate at least this many molecules of $\mathrm{TdR}$. If the doubling time is $1 \mathrm{~h}$ (as it was in the brackish water cultures), $6.4 \times 10^{6} \mathrm{TdR}$ molecules would have been incorporated during the $4 \mathrm{~h}$ incubations. Actually, each cell could only have $1.6 \times 10^{6}$ molecules, the rest being in sister cells.

Therefore, the cells in brackish-water cultures would have $\left(2.65 \times 10^{-7}\right) \times\left(1.6 \times 10^{6}\right)=0.42 \mathrm{dpm} \mathrm{cell}^{-1}$. During the $3 \mathrm{~d}$ ( $=4320 \mathrm{~min}$ ) of exposure, each cell will have experienced $0.42 \times 4320=1814$ disintegrations $(\beta$ particles emitted). Taking into account that, due to the geometry of the autoradiograms, half of the particles may not leave in the direction of the emulsion, 907 particles would still migrate into the emulsion. Assuming a conservative efficiency of 0.10 grains produced per particle emitted (Pelc 1972 p. 8, Williams 1977 Table 4.5, Rogers 1979), any cell taking most of its thymidine from the environment should produce about 70.9 grains of silver. Even if only a fourth of the thymines in DNA get labeled in tracer experiments, labeled cells would still be surrounded by 23 grains. Due to the low energy of $\beta$ particles emitted by tritium, all the grains exposed are in a limited area around the source of about $2 \mu \mathrm{m}$ diameter (Rogers 1979). Thus, under light microscopy, labeled cells should appear as 0.5 to $1 \mu \mathrm{m}$ cells surrounded by a $2 \mu \mathrm{m}$ sphere containing about 23 silver grains. This was precisely the appearance of the cells in our autoradiograms (Fig. 3). It is hard to imagine how a cell could be growing in the brackish-water cultures and not expose at least 2 silver grains if it were incorporating $\mathrm{TdR}$ as its main source of thymine in DNA. Even with the doubling times for the field samples (between 4 and $6 \mathrm{~h}$ on many occasions), the number of molecules incorporated during the $4 \mathrm{~h}$ incubations would be close to that maximum. Adding further evidence to our contention is the fact that cells were either surrounded by crowns of silver grains or not labeled (Fig. 3). Only a few cells had 2 or 3 grains. This is consistent with part of the community having adequate enzymes to incorporate external $T d R$ and part of the community lacking such enzymes.

In principle, measuring a conversion factor empirically from actual cell growth to thymidine uptake in diluted water cultures (Fuhrman \& Azam 1980, Kirchman et al. 1982a, Ducklow \& Kirchman 1983, Bell et al. 1983, Ducklow \& Hill 1985, Riemann et al 1987) should bypass this problem. Since cell number increases (as determined from AODC) correspond to the whole community, the conversion factor already takes into account those growing cells not taking up thymidine.

However, 2 conditions have to hold for this to be valid:

(1) The proportion of growing cells not taking up TdR has to be the same in cultures and natural samples.
Since the cells growing in the diluted water cultures are bigger than in natural communities, and conditions in such cultures are different (enclosure, no predators, low initial cell abundance), it is questionable whether such proportionality holds. Worse, there is no way, at present, of finding out.

(2) Calibrations have to be performed for every new habitat and at every set of different conditions (seasons, physical structure of the water column, etc.). The work of Riemann et al. (1987) comparing conversion factors at several coastal regions and very different temperatures suggests that the proportion may be fairly constant after all. If this proves to be true, the TdR method may still be used with confidence.

However, conversion factors can be more variable than the work of Riemann et al. suggests. They found 4

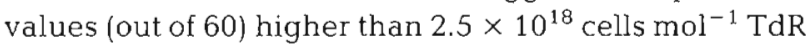
and many closer to 2 that to their average. We found factors 2 to 4 times higher than their average for some of the same waters (Table 1). Kirchman et al. (1982a) found factors as high as $4 \times 10^{18}$, Bell et al. (1983) calculated a factor of $2 \times 10^{18}$, and Lovell \& Konopka (1985) determined a factor of $2.2 \times 10^{18}$. Although some of the variability may be due to the use of subsaturating concentrations of $\mathrm{TdR}$, this is not the case in many others, where experiments were conducted to determine the saturating concentration of TdR. In any case, it seems clear that the conversion factor should be estimated for every new system analysed. Many workers have noted that several checks are necessary before the method can be applied confidently (Fuhrman \& Azam 1980, Findlay et al. 1984, Riemann 1984, Bell 1986, Moriarty 1986, Hollibaugh 1988).

Accurate values in the literature when an arbitrary value for the conversion factor was used are not to be expected. They are probably within an order of magnitude of the real value. This within order of magnitude is probably the reason why estimates from so many different methods and environments consistently give a figure of heterotrophic production approximately equal to $30 \%$ of net primary production (Cole et al. 1988). If we want a more detailed understanding of microbial activities in nature, however, the $\mathrm{TdR}$ technique should be combined with as many others as possible (Newell et al. 1986, Karl 1986). The TdR method is obviously not to be used as the perfect method for all systems and all bacterial communities, and the assumption that essentially all active heterotrophic bacteria in the field do take up TdR has to be questioned, if not rejected.

Acknowledgements. We thank Lorene Gassert, Eileen Hedick, and Mary Price for their help. C. P. -A. is particularly grateful to Evelyn and Barry Sherr for their spirited collaboration, and to the Sapelo Island Research Foundation for a Visiting Scientist grant. C.P.-A. received partial support from CICYT grant PB87-0183. 


\section{LITERATURE CITED}

Ammerman, J. W., Fuhrman, J. A., Hagströrn, A., Azam, F (1984). Bacterioplankton growth in sea water: I. Growth kinetics and cellular characteristics in seawater cultures. Mar Ecol. Prog. Ser. 18: 31-39

Bell, R. T (1986). Further verification of the isotope dilution approach for estimating the degree of participation of $\left({ }^{3} \mathrm{H}\right)$ thymidine in DNA synthesis in sudies of aquatic bacterial production. Appl. environ. Microbiol. 52 $1212-1214$

Bell, R. T., Ahlgren, G. M., Ahlgren, I. (1983). Estimating bacterioplankton production by measuring $\left({ }^{3} \mathrm{H}\right)$ thymidine incorporation in a eutrophic Swedish lake. Appl. environ. Microbiol. 45: 1709-1721

Bölter, M. (1981). DOC-turnover and microbial biomass production. Kiel Meeresforsch. Sonderh. 5: 304-310

Brock, T. D. (1967). Mode of filamentous growth of Leucothrix mucor in pure culture and in nature, as studied by tritiated autoradiography. J. Bacteriol. 93: 985-990

Brock, M. L., Brock, T D. (1968). The application of microautoradiographic techniques to ecological studies. Mitt. int. Verein. theor. angew. Limnol. 15, 1-29

Chalmers, A. G., Wiegert, R. G., Wolf, P. L. (1985). Carbon balance in a salt marsh: interactions of diffusive export, tidal deposition and rainfall-caused erosion. Estuar. coast. Shelf Sci. 21. 757-771

Cole, J. J., Findlay, S., Pace, M. L. (1988). Bacterial production in fresh and saltwater ecosystems: a cross-system overview. Mar. Ecol. Prog. Ser. 43: 1-10

Douglas, D. J., Novitsky, J. A., Fournier, R. O. (1987). Microautoradiography-based enumeration of bacteria with estimates of thymidine-specific growth and production rates. Mar. Ecol. Prog. Ser. 36: 91-99

Ducklow, H. W. (1982). Chesapeake Bay nutrient and plankton dynamics. 1. Bacterial biomass and production during a spring tidal destratification in the York River, Virginia, estuary. Limnol. Oceanogr. 27: 651-659

Ducklow, H. W. Hill, S. M. (1985). Tritiated thymidine incorporation and the growth of heterotrophic bacteria in warm core rings. Limnol. Oceanogr. 30: 260-272

Ducklow, H. W., Kirchman, D. L. (1983). Bacterial dynamics and distribution during a spring diatom bloom in the Hudson River plume, USA. J. Plankton Res. 5: 333-355

Fallon, R. D., Newell, S. Y., Sherr, B. F., Sherr, E. B. (1986). Factors affecting bacterial biomass and growth in the Duplin River estuary and coastal Atlantic Ocean. Actes Colloq. Int. Bacteriol. Mar. 3: 137-145

Findlay, S. E. G., Meyer, J. L., Edwards, R. T (1984). Measuring bacterial production via rate of incorporation of $\left({ }^{3} \mathrm{H}\right)$ thymidine into DNA. J. microbiol. Methods 2: 57-72

Fuhrman, J. A., Azam, F. (1980). Bacterioplankton secondary production estimates for coastal waters of British Columbia, Antarctica, and California. Appl, environ. Microbiol. 39: 1085-1095

Fuhrman, J. A., Azam, F. (1982). Thymidine incorporation as a measure of heterotrophic bacterioplankton production in marine surface waters: evaluation and field results. Mar. Biol. 66: 109-122

Hagström, §̊, Larsson, U., Höstedt, P., Normark, S. (1979). Frequency of dividing cells, a new approach to the determination of bacterial growth rates in aquatic environments. Appl. environ. Microbiol. 37: 805-812

Hobbie, J. E., Daley, R. J., Jasper, S. (1977). Use of Nuclepore filters for counting bacteria by fluorescence microscopy Appl. environ. Microbiol. 33: 1225-1228.

Hollibaugh, J. T. (1988). Limitations of the $\left[{ }^{3} \mathrm{H}\right.$-thymidine method for estimating bacterial productivity due to thymidine metabolism. Mar. Ecol. Prog. Ser. 43: 19-30

Hoppe, H.-G. (1977). Determinations and properties of actively metabolizing heterotrophic bacteria in the sea investigated by means of microautoradiography. Mar. Biol. 36: 291-302

Imberger, J., Berman, T., Christian, R. R., Sherr, E. B., Whitney, D. E., Pomeroy, L. R., Wiegert, R. G., Wiebe, W. J. (1983). The influence of water motion on the distribution and transport of materials in a salt marsh estuary. Limnol. Oceanogr. 28: 201-214

Ingraham, J. L., Maaløe, O., Neidhardt, F. C. (1983). Growth of the bacterial cell. Sinauer Associates, Sunderland, Mass.

Karl, D. M. (1979). Measurement of microbial activity and growth in the ocean by rates of stable ribonucleic acid synthesis. Appl. environ. Microbiol. 38: 850-860

Karl, D. M. (1986). Determination of in situ microbial biomass, viability, metabolism, and growth. In: Poindexter, J. S. Leadbetter, E. R. (eds.) Bacteria in nature, Vol. 2. Plenum, New York, p. 85-176

Kirchman, D., Ducklow, H. W., Mitchell, R. (1982a). Estimates of bacterial growth from changes in uptake rates and biomass. Appl. environ. Microbiol. 44: 1296-1307

Kirchman, D., Sigda, J., Kapuscinski, R., Mitchell, R. (1982b). Statistical analysis of the direct count method for enumerating bacteria. Appl. environ. Microbiol. 44: 376-382

Long, E. C. (1977). Applications of quench monitoring by Compton edge effect: the ' $H^{\# \prime}$. Technical Rep. 1096-NUC77-2T Beckman instruments, Fullerton, California

Lovell, C. R., Konopka, A. (1985). Seasonal bacterial production in a dimictic lake as measured by increases in cell numbers and thymidine incorporation. Appl. environ. Microbiol. 49: 492-500

Meyer-Reil, L.-A. (1978). Autoradiography and epifluorescence microscopy combined for the determination of number and spectrum of actively metabolizing bacteria in natural waters. Appl. environ. Microbiol. 36: 506-512

Moriarty, D. J. W. (1986). Measurement of bacterial growth rates in aquatic systems using rates of nucleic acid synthesis. Adv. microb. Ecol. 9: 245-292

Newell, S. Y (1984). Modification of the gelatin-matrix method for enumeration of respiring bacterial cells, for use with salt-marsh water samples. Appl. environ. Microbiol. $47: 873-875$

Newell, S. Y., Christian, R. R. (1981). Frequency of dividing cells as an estimator of bacterial productivity. Appl. environ. Microbiol. 42: 23-31

Newell, S. Y., Fallon, R. D. (1982). Bacterial productivity in the water column and sediments of the Georgia (USA) coastal zone: estimates via direct counting and parallel measurement of thymidine incorporation. Microb. Ecol. 8: 33-46

Newell, S. Y., Fallon, R. D., Tabor, P. S. (1986). Direct microscopy of natural assemblages. In: Poindexter, J. S., Leadbetter, E. R. (eds.) Bacteria in nature, Vol. 2. Plenum, New York, p. $1-48$

Newell, S. Y., Fallon, R. D., Sherr, B. F., Sherr, E. B. (1988). Mesoscale temporal variation in bacterial standing crop, percent active cells, productivity and output in a saltmarsh tidal river. Verh. int. Verein. Limnol. 23: 1839-1845

Novitsky, J. A. (1983a). Heterotrophic activity through a vertical profile of seawater and sediment in Halifax Harbour, Canada. Appl. environ. Microbiol. 45: 1753-1760

Novitsky, J. A. (1983b). Microbial activity at the sediment water interface in Halifax Habor, Canada. Appl. environ. Microbiol. 45: 1761-1766

Paerl, H. W., Stull, E. A. (1979). In defense of grain density autoradiography. Limnol. Oceanogr. 24: 1166-1169 
Pedrós-Alió, C., Brock, T D. (1982). Assessing biomass and production of bacteria in eutrophic Lake Mendota, Wisconsin. Appl environ. Microbiol. 44: 203-218

Pelc, S. R. (1972). Theory of autoradiography. In: Graham, P. B. (ed.) Autoradiography for biologists. Academic Press, London, p. 1-17

Pomeroy, L. R., Wiegert, R. G. (eds.) (1981). The ecology of a salt marsh. Springer Verlag, New York

Ragotzkie, R. A., Bryson, R. A. (1955). Hydrography of the Duplin River, Sapelo Island, Georgia. Bull mar. Sci. 5: $297-314$

Riemann, B. (1984). Determining growth rates of natural assemblages of freshwater bacteria by means of ${ }^{3} \mathrm{H}$-thymidine incorporation into DNA: comments on methodology. Arch. Hydrobiol. Beih. Ergebn. Limnol. 19: 67-80

Riemann, B., Bjørsen, P. K., Newell, S. Y., Fallon, R. D. (1987). Calculation of cell production of coastal marine bacteria based on measured incorporation of $\left[{ }^{3} \mathrm{H}\right]$ thymidine. Limnol. Oceanogr. 32: 471-476

Riemann, B., Nielsen, P., Jeppesen, M., Marcussen, B., Fuhrman, J. A. (1984). Diel changes in bacterial biomass and growth rates in coastal environments, determined by means of thymidine incorporation into DNA, frequency of dividing cells (FDC), and microautoradiography. Mar. Ecol. Prog. Ser. 17: 227-235

Riemann, B., Sendergaard, M., Schierup, H.-H., Bosselman, S., Christensen, G., Hansen, J., Nielsen, B. (1982). Carbon metabolism during a spring diatom bloom in eutrophic Lake Mossø. Int. Revue ges. Hydrobiol. 67: 145-185

This article was submitted to the editor
Rogers, A. W. (1979). Techniques of autoradiography, 3rd edn. Elsevier/North Holland, Amsterdarn

Sherr, E. B., Sherr, B. F. (1987). High rates of consumption of bacteria by pelagic ciliates. Nature, Lond. 325: 710-711

Sherr, B. F., Sherr, E. B., Pedrós-Alió C. (1989). Simultaneous measurement of bacterioplankton production and protozoan bacterivory in estuarine water Mar. Ecol. Prog. Ser. 54: $209-219$

Simek, K. (1986). Bacterial activity in a reservoir determined by autoradiography and its relationship to phyto- and zooplankton. Int Revue ges. Hydrobiol 71: 593-612

Staley, J. T., Konopka, A. (1985). Measurement of in situ activities of nonphotosynthetic microorganisms in aquatic and terrestrial habitats. Ann. Rev. Microbiol. 39: 321-346

Tabor, P. S., Neihof, R. A. (1982). Improved microautoradiographic method to determine individual microorganisms active in substrate uptake in natural waters. Appl. environ Microbiol 44: 945-953

Tabor, P. S., Neihof, R. A. (1984). Direct determination of activities for microorganisms of Chesapeake Bay populations. Appl. environ. Microbiol. 48: 1012-1019

van Es, F. B., Meyer-Reil, L.-A. (1982). Biomass and metabolic activity of heterotrophic marine bacteria. Adv. microb. Ecol. 6: 111-170

Williams, M. A. (1977). Autoradiography and immunocytochemistry. In: Glauert, A. M. (ed.) Practical methods in electron microscopy, Vol. 6, Part 1, North-Holland, Amsterdam, p. 1-217

Manuscript first received: May 3,1988

Revised version accepted April 17, 1989 